\title{
Liquid Organic Fertilizer Effects on Growth and Biomass of Lettuce Grown in a Soilless Production System
}

\author{
Azeezahmed Shaik \\ Department of Plant and Soil Science, College of Agricultural Sciences \\ and Natural Resources, Texas Tech University, Lubbock, TX 79409 \\ Hardeep Singh
Department of Agronomy, Kansas State University, Manhattan, KS 66506 \\ Sukhbir Singh \\ Department of Plant and Soil Science, College of Agricultural Sciences \\ and Natural Resources, Texas Tech University, Lubbock, TX 79409
}

\section{Thayne Montague}

Department of Plant and Soil Science, College of Agricultural Sciences and Natural Resources, Texas Tech University, Lubbock, TX 79409; and Texas A\&M University, Texas A\&M AgriLife Research Extension Center, Lubbock, TX 79403

\section{Jacobo Sanchez}

Department of Plant and Soil Science, College of Agricultural Sciences and Natural Resources, Texas Tech University, Lubbock, TX 79409; and U.S. Department of Agriculture-Agricultural Research Service, Lubbock, $T X 79401$

Additional index words. butterhead lettuce, chlorophyll content, growth parameters, plant-animal-based organic fertilizers, water-soluble organic fertilizers

\begin{abstract}
Demand for locally produced, organically grown leafy greens is increasing throughout the United States. However, due to lack of efficient organic fertilizers (OFs) for soilless substrates, organic greenhouse production of leafy greens may be challenging. Therefore, a greenhouse study was conducted to analyze the effects of six liquid OFs on growth and development of lettuce in a soilless system. Two experiments were conducted using a randomized block design, and treatments included six fish- or plant-based OFs: $\mathrm{OF}_{1}(5 \mathrm{~N}-1 \mathrm{P}-1 \mathrm{~K}), \mathrm{OF}_{2}(2 \mathrm{~N}-5 \mathrm{P}-1 \mathrm{~K}), \mathrm{OF}_{3}(3 \mathrm{~N}-1 \mathrm{P}-1 \mathrm{~K}), \mathrm{OF}_{4}(2 \mathrm{~N}-2 \mathrm{P}-2 \mathrm{~K}), \mathrm{OF}_{5}(4 \mathrm{~N}-1 \mathrm{P}-1 \mathrm{~K})$, and $\mathrm{OF}_{6}(3 \mathrm{~N}-3 \mathrm{P}-2 \mathrm{~K})$; one inorganic fertilizer treatment (IF, 24N-8P-16K); and one unfertilized control treatment. Fertilizer solutions were prepared at $2 \mathrm{dS} \cdot \mathrm{m}^{-1}$ and applied at 100 $\mathrm{mL} /$ plant. In Expt. 1, fresh biomass for IF-treated plants was $12 \%$ to $38 \%$ greater than OF treatments, whereas this difference ranged from $25 \%$ to $57 \%$ in Expt. 2. Similarly, leaf area values of IF-treated plants were $5 \%$ to $40 \%$ greater than OF treatments in Expt. 1, and the difference ranged from $28 \%$ to $90 \%$ in Expt. 2. A possible explanation could be greater availability of nutrients in the IF treatment compared with OF treatments. There was no significant difference among fertilized treatments for number of leaves and stem diameter. Based on the index-based ranking, fish-based $\left(\mathrm{OF}_{1}\right)$ and fish- and plant-based $\left(\mathrm{OF}_{2}\right.$ and $\left.\mathrm{OF}_{6}\right)$ performed well among different liquid $\mathrm{OFs}$ used in the study. Although the yield under OFs was less compared with that under IF, there is potential to reduce this yield gap by optimized fertility management of these fertilizers. Future research is needed to investigate the impact of optimized rate, timing, different placement, and additional nitrogen $(\mathrm{N})$ sources of OFs on the soilless production of lettuce.
\end{abstract}

By providing biologically active substances such as vitamins, dietary fiber, antioxidants, and cholesterol-lowering compounds, vegetables play a vital role in human nutrition

Received for publication 27 Oct. 2021. Accepted for publication 6 Dec. 2021.

Published online 4 February 2022.

S.S. is the corresponding author. E-mail: s.singh@ttu.edu.

This is an open access article distributed under the CC BY-NC-ND license (https://creativecommons. org/licenses/by-nc-nd/4.0/).
(Hounsome et al., 2008). Accordingly, a cultural shift toward healthier lifestyles and sustainable food production systems has emerged throughout the developed world (Reganold and Wachter, 2016). As a result, worldwide consumer demand for organic vegetables has increased significantly in recent years (Willer and Lernoud, 2019; Willer and Sahota, 2020; Willer et al., 2008). In addition, the number of operations producing organic vegetables has also increased. In the United States, sales and hectares for open-field conventional (nonorganic) vegetable production in 2017 were
\$19.6 billion and 1.6 million ha, respectively (Table 1). In comparison, open-field organic production sales and acreage for the previous year (2016) were \$1.64 billion and 0.075 million ha, respectively (Table 1). On a per-hectare basis, vegetable production from open organic systems had about two-times greater sales value than open conventional systems (Table 1). Similarly, covered systems such as greenhouses and high tunnels had significantly greater sales value than open systems regardless of type (organic vs. conventional) over the same time. For example, in 2015 , covered organic vegetable systems had gross sales of $\$ 534,321 /$ ha compared with $\$ 18,157 /$ ha for open organic systems (Table 1).

The dietary guidelines for Americans recommend five servings of vegetables per day based on an intake of 2000 calories (Stewart and Hyman, 2019). It is also recommended one of the five servings of vegetables should be leafy green vegetables. One of the most used leafy green vegetables is lettuce ( $\mathrm{Lac}$ tuca sativa L.), a member of the sunflower family Asteraceae (Ryder, 1999). Today, lettuce is the most widely grown fresh vegetable in the United States (Ryder, 1999). Annually, per-capita lettuce consumption in the United States is $\approx 5.1 \mathrm{~kg}$ (Shahbandeh, 2021), which is five times greater than consumption a century ago. Lettuce is an excellent source of vitamin $A$, vitamin $C$, vitamin $K$, some $B$ vitamins, and other phytonutrients (Kim et al., 2016). In addition, dark-green and red leaves of certain lettuce varieties provide a greater overall nutritional value when compared with varieties with lighter green leaves (Bunning and Kendall, 2012).

Greenhouse soilless cultivation of leafy greens has been shown to produce greater yields when compared with field cultivation on the basis of area under production (Greer and Diver, 2000). Greenhouse soilless production systems have been used to grow high-value and high-demand vegetable crops such as tomato (Solanum lycopersicum L.), cucumber (Cucumis sativus L.), bell pepper (Capsicum annuum L.), eggplant (Solanum melongena L.), and leafy greens [lettuce, arugula (Eruca vesicaria L.), spinach (Spinacia oleracea L.), kale (Brassica oleracea var. sabellica L.), and Swiss chard (Beta vulgaris ssp. cicla L.)] (Walters et al., 2020). These systems use organic potting mixes, or other inert media, for providing support to the plant (Greer and Diver, 2000). Because of the availability of little to no plant-available nutrients in inert media, leafy green producers face the challenge of providing adequate nutrients to plants, especially in organic production (Tittarelli, 2020). In addition, because plants in these systems grow very rapidly as a result of optimized growth conditions, synchronizing nutrient availability and nutrient demand becomes more critical in greenhouse production systems (Tei et al., 1996). Hence, proper selection of an OF source and media substrate (Rahman et al., 2019) is critical for providing the necessary nutrition to maintain production quality and yield standards in greenhouse soilless cultivation. 
Table 1. Production statistics for U.S. organic and conventional vegetable production systems.

\begin{tabular}{lrrrl}
\hline Yr & Sales $(\$)$ & ha & Sales $(\$ /$ ha $)$ & Type \\
\hline $2017^{\mathrm{z}}$ & $19,583,739,000$ & $1,604,832$ & 12,203 & Open conventional \\
2012 & $16,851,235,000$ & $1,691,948$ & 9,960 & Open conventional \\
2007 & $14,683,058,000$ & $1,763,168$ & 8,328 & Open conventional \\
2002 & $12,785,898,000$ & $1,389,396$ & 9,202 & Open conventional \\
2016 & $1,644,431,203$ & 75,344 & 21,826 & Open organic \\
2015 & $1,361,747,498$ & 74,998 & 18,157 & Open organic \\
2014 & $1,247,666,655$ & 66,266 & 18,828 & Open organic \\
2011 & $1,071,694,396$ & 47,782 & 22,429 & Open organic \\
2008 & $685,311,003$ & 52,786 & 12,983 & Open organic \\
2017 & $748,301,654$ & 1,046 & 715,394 & Covered conventional \\
2012 & $634,486,003$ & 911 & 696,472 & Covered conventional \\
2007 & $553,034,688$ & 574 & 963,475 & Covered conventional \\
2015 & $73,201,940$ & 137 & 534,321 & Covered organic \\
2014 & $75,857,306$ & 182 & 416,798 & Covered organic \\
\hline zUS. Department & of Agriculture-National Agricultural Statistics Service (https://www.nass.usda.gov/).
\end{tabular}

${ }^{\mathrm{z} U . S . ~ D e p a r t m e n t ~ o f ~ A g r i c u l t u r e-N a t i o n a l ~ A g r i c u l t u r a l ~ S t a t i s t i c s ~ S e r v i c e ~(h t t p s: / / w w w . n a s s . u s d a . g o v /) . ~}$

In organic production, selection of plant and seed material, fertilizer sources, and pest management systems are governed by stringent, organic, certified cultural practices and guidelines issued by the U.S. Department of Agriculture. Therefore, the choice of fertilizer has to be from sources certified as organic by the Organic Material Review Institute (OMRI). Mostly, OFs from plant and animal sources such as blood meal, meat and bone meal, fish meal, seabird guano, chicken manure, poultry manure, and turkey manure are often used for in-ground (i.e., soil-based) organic vegetable production (Bi et al., 2010; Gaskell et al., 2007; Hartz and Johnstone, 2006). A significant challenge with organic residue-based fertilizers in soilless systems is nitrogen mineralization. Nitrogen mineralization affects the efficacy and timing of the nutrient supply to meet the demand of vegetable crops at critical stages of development (Treadwell et al., 2007), which in turn affects yield and quality of produce. Soilbased systems include microflora that facilitate mineralization of OFs. However, microflora are absent in soilless systems. Therefore, mineralization of OF sources in soilless systems are affected, and thus the bioavailability of nutrients to the plant is also reduced (Gaskell and Smith, 2007; Paillat et al., 2020). For this reason, use of OFs that do not require further mineralization is important for optimizing organic vegetable production under soilless greenhouse conditions (Bi et al., 2010).

Commercially available liquid OFs could fill this gap in providing adequate fertility to greenhouse-grown vegetables. Commercial liquid $\mathrm{OFs}$ are manufactured from various plant and animal residue wastes, such as fish hydrolysates, emulsions from seaweed and fish, and oilseed extract (Burnett et al., 2016).
These fertilizers are highly refined and concentrated forms developed by digesting animal- and plant-based organic waste at high temperatures, or by microbial digestion. Moreover, these liquid OFs contain plant-available macro- and micronutrients that may improve growth and yield of vegetables in organic soilless production systems. However, unlike IFs, research on the use of liquid OF in soilless greenhouse vegetable production is very limited (Treadwell et al., 2007). Within these contexts, the objective of our study was to evaluate the effect of six commercially available liquid OFs (derived from fish and plant sources) on growth and yield of butterhead lettuce cv. Rex grown in a soilless system under greenhouse conditions.

\section{Materials and Methods}

Experimental site and growth conditions. Two experiments were conducted in a glasshouse at the horticulture gardens and greenhouse complex, Department of Plant and Soil Science, Texas Tech University, Lubbock, TX (lat. $33^{\circ} 35^{\prime} 03.3^{\prime \prime} \mathrm{N}$, long. $101^{\circ} 53^{\prime} 13.2^{\prime \prime} \mathrm{W}$; elevation, $979 \mathrm{~m}$ above mean sea level). Expt. 1 was conducted in the north portion of an east-west-oriented glasshouse from 6 Oct. to 24 Nov. 2019. Expt. 2 was conducted on the south side of the same glasshouse from 18 Nov. 2019 to 6 Jan. 2020. The average temperature inside the greenhouse for both experiments was $22^{\circ} \mathrm{C}$ and an average humidity was $60 \%$. The soilless substrate used in each experiment was Resilience Silicon Enriched Metro-Mix MM 902 RSi (Sun Gro Horticulture, Agawam, MA). Substrate consisted of $45 \%$ to $55 \%$ processed softwood bark, $25 \%$ sphagnum peatmoss, $20 \%$ vermiculite, and $5 \%$ to $10 \%$ perlite.

Seed sowing and transplanting. Pelleted seeds of butterhead lettuce cv. Rex (Johnny's Selected Seeds, Winslow, ME) were sown into 72-cell plug trays (Hydrofarm, Petaluma, CA) on 6 Oct. and 18 Nov. 2019 in Expts. 1 and 2, respectively. Seedlings at the four-leaf stage were transplanted to $10-\mathrm{cm}$-diameter plastic $(100-\mathrm{mL})$ pots filled with soilless substrate on 24 Oct. and 6 Dec. 2019 for Expts. 1 and 2, respectively.

Fertilizer treatments and their nutrient composition. Liquid $\mathrm{OF}$ treatments included $\mathrm{OF}_{1} \quad(5 \mathrm{~N}-1 \mathrm{P}-1 \mathrm{~K}), \quad \mathrm{OF}_{2} \quad(2 \mathrm{~N}-5 \mathrm{P}-1 \mathrm{~K}), \mathrm{OF}_{3}$ $(3 \mathrm{~N}-1 \mathrm{P}-1 \mathrm{~K}), \mathrm{OF}_{4}(2 \mathrm{~N}-2 \mathrm{P}-2 \mathrm{~K}), \mathrm{OF}_{5}(4 \mathrm{~N}-1 \mathrm{P}-$ $1 \mathrm{~K})$, and $\mathrm{OF}_{6}(3 \mathrm{~N}-3 \mathrm{P}-2 \mathrm{~K})$ (Table 2). In addition, an IF $(24 \mathrm{~N}-8 \mathrm{P}-16 \mathrm{~K})$ and a no-fertilizer treatment/control (C) were included. All liquid OFs were listed under OMRI for organic crop production. Different sources and nutrient compositions of these OFs and IF are presented in Table 2. Each treatment was prepared in a 49-L-capacity plastic container by using reverse-osmosis (RO) water with a final electrical conductivity (EC) of $2.0 \mathrm{dS} \cdot \mathrm{m}^{-1}$ (Orion Star A329 pH/ISE/Conductivity/Dissolved Oxygen Portable Multiparameter Meter; Thermo Fisher Scientific, Waltham, MA). The $\mathrm{pH}, \mathrm{EC}$, and total dissolved solids (TDS) of the prepared nutrient solution were measured before each application. On alternate days, respective fertilizer treatments and RO water were applied at $100 \mathrm{~mL} /$ plant. For the duration of each experiment, the control treatment received $100 \mathrm{~mL}$ of RO water every day.

Experimental design and data collection. Experiments were a randomized complete block design with four replicates. There were six plants in each replication, and a total of 192 plants in each experiment. All pots were placed in a $9.0-\mathrm{m}^{2}$ area, with $20-\mathrm{cm}$ spacing between plants. During the growing season, chlorophyll content was estimated (sixth leaf from plant center) from six plants from each replication at $7,14,21$, and $28 \mathrm{~d}$ after transplanting (DAT) using a soil plant analysis development (SPAD) meter (Minolta SPAD 502 digital chlorophyll meter; Spectrum Technologies, Plainfield, IL). Chlorophyll concentration (measured in micromoles per square meter) was calculated using a methodology that converts SPAD values to micromoles per unit leaf area (Parry et al., 2014). At the end of each growing season, four plants from each replication were harvested, and yield parameters such as fresh biomass, number of leaves, total leaf area, stem diameter, and plant dry biomass were measured and calculated on a per-plant

Table 2. Organic and inorganic fertilizers used in our study at Lubbock, TX.

\begin{tabular}{|c|c|c|c|c|c|c|}
\hline ID & Product name & Source & $\mathrm{N}-\mathrm{P}-\mathrm{K}$ & Biocomposition & Certification & Manufacturer \\
\hline$\overline{\mathrm{IF}}$ & Peter Professional & Inorganic & $24 \mathrm{~N}-8 \mathrm{P}-16 \mathrm{~K}$ & Nitrate salts, urea & Synthetic & Peter Professional, Summerville, SC \\
\hline $\mathrm{OF}_{1}$ & Alaska fish fertilizer & Organic & $5 \mathrm{~N}-1 \mathrm{P}-1 \mathrm{~K}$ & Fermented fish & OMRI listed & Lilly Miller, Atlanta, GA \\
\hline $\mathrm{OF}_{2}$ & Drammatic K fertilizer & Organic & $2 \mathrm{~N}-5 \mathrm{P}-1 \mathrm{~K}$ & Fermented fish, kelp & OMRI listed & Dramm Corp, Manitowoc, WI \\
\hline $\mathrm{OF}_{3}$ & Nature's Source organic & Organic & $3 \mathrm{~N}-1 \mathrm{P}-1 \mathrm{~K}$ & Fermented oilseed extract & OMRI listed & Nature's Source, Sherman, TX \\
\hline $\mathrm{OF}_{4}$ & Kellogg organic plus fertilizer & Organic & $2 \mathrm{~N}-2 \mathrm{P}-2 \mathrm{~K}$ & Ocean fish, molasses, kelp & OMRI listed & Kellogg Garden, Carson, CA \\
\hline $\mathrm{OF}_{5}$ & SuperThrive organic fertilizer & Organic & $4 \mathrm{~N}-1 \mathrm{P}-1 \mathrm{~K}$ & Fermented fish & OMRI listed & SuperThrive, Seekonk, MA \\
\hline $\mathrm{OF}_{6}$ & AgroThrive organic biofertilizer & Organic & $3 \mathrm{~N}-3 \mathrm{P}-2 \mathrm{~K}$ & Fermented fish, grain & OMRI listed & AgroThrive, Gonzales, CA \\
\hline
\end{tabular}

ID = identification; OF = organic fertilizer; IF = inorganic fertilizer; OMRI = Organic Materials Review Institute. 
Table 3. Performance rank versus cumulative rank index (RI) of the six organic fertilizers (OFs) compared with inorganic fertilizer in soilless lettuce (Lactuca sativa cv. Rex) greenhouse production at Lubbock, TX.

Fresh Leaf No. of Dry

Treatment biomass area leaves biomass RI

\begin{tabular}{lllllr}
\hline $\mathrm{OF}_{1}$ & 1 & 2 & 1 & 2 & $6(1)^{2}$ \\
$\mathrm{OF}_{2}$ & 2 & 1 & 4 & 1 & $8(2)$ \\
$\mathrm{OF}_{6}$ & 3 & 3 & 2 & 3 & $11(3)$ \\
$\mathrm{OF}_{4}$ & 5 & 6 & 3 & 4 & $18(4)$ \\
$\mathrm{OF}_{5}$ & 4 & 4 & 5 & 6 & $19(5)$ \\
$\mathrm{OF}_{3}$ & 6 & 5 & 6 & 5 & $22(6)$ \\
\hline
\end{tabular}

${ }^{\mathrm{z}}$ Numbers in parentheses are the RI-based rank of each OF.

basis by dividing the total of each metric by four. Fresh biomass of a plant was recorded immediately after harvest using a weighing balance (Ohaus R31P15, Ranger 3000 Compact Bench Scale; Ohaus, Parsippany, NJ). The number of leaves from each plant was counted manually, and leaf area of was measured with a leaf area meter (LI-3100C; LI-COR, Lincoln, $\mathrm{NE}$ ). The stem diameter of each plant was measured with digital caliper (Carrera Precision, Max Tool, Ontario, CA). To quantify dry biomass, plants were oven dried at $60^{\circ} \mathrm{C}$ for $72 \mathrm{~h}$ and then weighed.

Index-based ranking. An index-based ranking was used for different OFs based on performance of the plant in each treatment compared with the IF treatment by data polling from both experiments (Table 3). Percentage change values (Supplemental Table 1) were used to assign performance ranks to each $\mathrm{OF}$, with 1 point being the best performer and 6 points being the worst performer among all OFs (Table 3). Scores ranging from 1 to 6 points were assigned to each OF and added to determine the cumulative rank index (RI). The fertilizer treatment with the lowest RI was considered the best performer among OF treatments when compared with IF.

Statistical analysis. All data were analyzed statistically using the JMP statistical analysis software package (JMP, version 14.3; SAS Institute Inc., Cary, NC). Following a significant analysis of variance at $P<$ 0.05 , differences among treatment means were compared using the Tukey-Kramer honestly significant difference test.

\section{Results and Discussion}

Greenhouse shading effects on lettuce growth during our study. Our production system involved conducting two experiments in a glasshouse with the glass roof positioned in an east-west direction, providing maximal sunlight in the greenhouse area. However, although the temperature was maintained at close to optimal levels, the lighting conditions were variable as a result of structural shading. The two experiments were both conducted during Fall and Winter 2019, and as such the sun angle differed to some degree for both experiments. As a result, the orientation of the greenhouse allowed for a shadow to be cast over the area where the plants were situated. Expt. 1 was conducted in the north bay, where a significant amount of shading was present; Expt. 2 was conducted in the south bay, where there was significantly less shading. Although the plants were randomized in both iterations of our experiment, randomization was not sufficient to account for this shading. As such, the growth and development of the lettuce plants varied between Expt. 1 (24 Oct.-24 Nov. 2019) and Expt. 2 (6 Dec. 2019-6 Jan. 2020). Nonetheless, the two experiments were sufficient to assess the fertility capacity of the inorganic and organic formulations tested.

Leaf area and number of leaves. In each experiment, the leaf area of lettuce plants was greater in all OF treatments compared with the control treatment (Fig. 1A). However, in each experiment lettuce plants produced from IF treatments produced the greatest leaf area compared with all other treatments. Leaf area values of IF-treated plants were $5 \%$ and $40 \%$ greater than $\mathrm{OF}_{2}$ (the greatest leaf area producer among $\mathrm{OF}$ treatments) and $\mathrm{OF}_{3}$ (the lowest leaf area producer among OFs), respectively, in Expt. 1. Values were 28\% and 90\% greater than $\mathrm{OF}_{1}$ (the greatest leaf area producer among $\mathrm{OFs}$ ) and $\mathrm{OF}_{4}$ (the lowest leaf area producer among $\mathrm{OFs}$ ), respectively, in Expt. 2. Similar results were observed in a soilless greenhouse study conducted by Zandvakili et al. (2019). Researchers assessed the effects of OF solution on the growth and composition of lettuce, with a comparison of Hoagland and Arnon solution and no fertilization. Researchers observed the leaf area of different lettuce varieties grown with Hoagland and Arnon solution treatment were $184 \%$ and $537 \%$ greater than OF and unfertilized treatments, respectively. Although in our study differences in leaf area were present for all treatments across each experiment, $\mathrm{OF}_{1}, \mathrm{OF}_{2}$, and $\mathrm{OF}_{6}$ (fish-based $\mathrm{OFs}$ ) were consistent top performers among all OFs. Similar to these results, Ekinci et al. (2019) also reported the greatest leaf area in spinach when treated with fish manure in combination with IF. The possible reason for this could be fish fertilizer acts
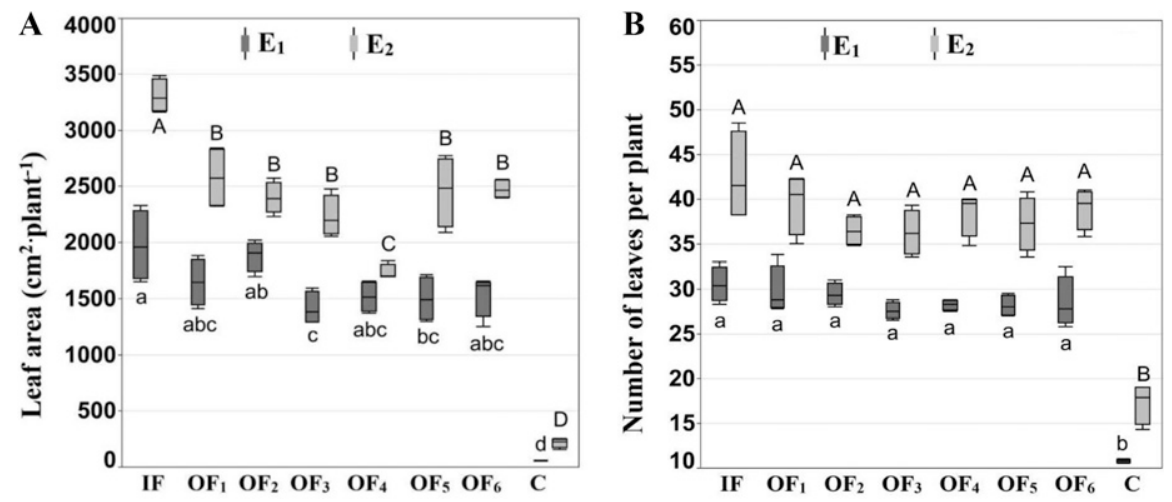

Fig. 1. Butterhead lettuce (Lactuca sativus cv. Rex) leaf area (A) and number of leaves per plant (B) measured at $30 \mathrm{~d}$ after transplanting in Expt. $1\left(\mathrm{E}_{1}\right)$ and Expt. $2\left(\mathrm{E}_{2}\right)$ in Lubbock, TX. Box plots represent the mean \pm SE of four replications. Box plots following the same letter in each experiment are not significantly different; lowercase letters are for $E_{1}$ and uppercase letters are for $E_{2}$. $C=$ no fertilizer treatment; IF = inorganic fertilizer, $\mathrm{OF}=$ organic fertilizer. as a good rooting media conditioner and helps in root development (Irshad et al., 2006), which increases nutrient uptake and leads to greater plant leaf area.

Similar to leaf area, number of leaves per plant were also greater in all OF treatments compared with the control treatment in Expts. 1 and 2. Although leaf area showed differences among fertilizer treatments, number of leaves per plant among IF and OF treatments were not different across Expts. 1 and 2 (Fig. 1B). Leaf number values of IF-treated plants were $3 \%$ and $11 \%$ greater than $\mathrm{OF}_{1}$ (the greatest number of leaves among $\mathrm{OFs}$ ) and $\mathrm{OF}_{3}$ (the lowest number of leaves among OFs), respectively in Expt. 1, and the same values were 7\% and $17 \%$ greater than $\mathrm{OF}_{1}$ and $\mathrm{OF}_{3}$, respectively, in Expt. 2. Similarly, Moncada et al. (2021) reported the greatest number of leaves of basil plants (Ocimum basilicum L.) under IF, and a progressive decrease with the increase in an OF component in the fertigation formula. The difference in growth (leaf area or leaf number) between IF and OFs can be attributed to differences in the availability of nutrients, especially N (Ellis and Foth, 1996). The lower nutrient availability in OFs for plant growth led to less growth and yield of lettuce compared with IFs. Moreover, the leaf number values of IF and $\mathrm{OF}_{1}$ treatments were $187 \%$ and $174 \%$ greater than the control treatment, respectively in Expt. 1, and the same values were $146 \%$ and $129 \%$ greater than the control, respectively, in Expt. 2. Therefore, data also indicate nutrient uptake of lettuce was effective under OF treatments and was comparable to that in IF treatment.

Stem diameter. In both experiments, the stem diameter of lettuce plants was larger in all fertilized treatments when compared with the control (Fig. 2A). The $\mathrm{OF}_{4}$ treatment recorded the greatest stem diameter during each experiment. The stem diameter of lettuce in treatment $\mathrm{OF}_{4}$ was $148 \%$ and $115 \%$ greater when compared with the control (treatment with smallest stem diameter) in Expts. 1 and 2, respectively. In Expt. 1, the stem diameter under $\mathrm{OF}_{4}$ was greater $(18 \%)$ than IF treatment, and all other OF treatments except $\mathrm{OF}_{2}$. 


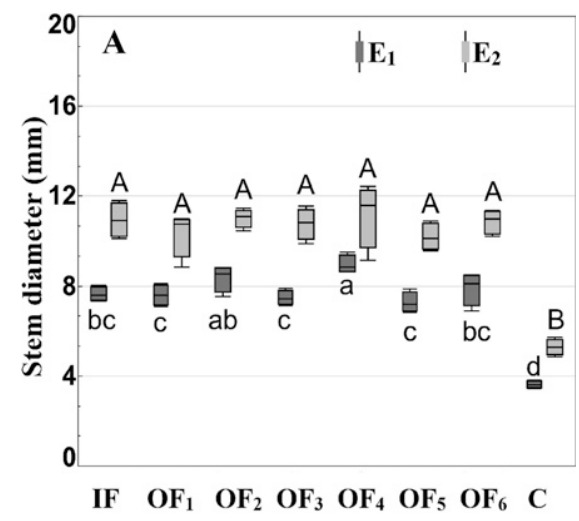

Fig. 2. Butterhead lettuce (Lactuca sativus cv. Rex) stem diameter measured at $30 \mathrm{~d}$ after transplanting in Expt. $1\left(\mathrm{E}_{1}\right)$ and Expt. $2\left(\mathrm{E}_{2}\right)$ in Lubbock, TX. Box plots represent mean \pm SE of four replications. Box plots following the same letter in each experiment are not significantly different; lowercase letters are for Expt. 1 and uppercase letters are for Expt. 2. $\mathrm{C}=$ no fertilizer treatment; $\mathrm{IF}=$ inorganic fertilizer, $\mathrm{OF}=$ organic fertilizer.

In addition to fish, both $\mathrm{OF}_{4}$ and $\mathrm{OF}_{2}$ included kelp in their fertilizer composition. As an OF, kelp is reported to increase the stem diameter of vegetables such as broccoli (Brassica oleracea var. italica L.) and cabbage (B. oleracea var. capitata L.) (Aldworth and Staden, 1987; Mattner et al., 2013). Furthermore, by enhancing the actions of growth regulators (particularly cytokinins, auxins, betaines, sterols, and organic polymers), in these studies kelp increased early plant growth and stem diameter (Craigie, 2011). In addition, Ali et al. (2021) reported seaweed-based products have phytostimulatory properties that help to increase plant growth and yield parameters such as stem diameter and leaf area. However, stem diameter was not different among OFs and IF treatments, but greater than the control treatment in Expt. 2 (Fig. 2A).

Chlorophyll content. The chlorophyll content of lettuce leaves in different fertilizer treatments followed a similar trend, with the peaks at 14 or 21 DAT for most fertilizer treatments in Expts. 1 and 2 (Fig. 3). The exception was $\mathrm{OF}_{3}$ where chlorophyll content increased until 28 DAT in each experiment. The chlorophyll content of plant leaves is considered a very good abiotic stress indicator (drought or nutrient stresses) (Arunyanark et al., 2008). As growth of lettuce is exponential (Marcelis et al., 1998), growth from 2 weeks and onward is characterized by rapid growth and expansion of leaves (Shimizu et al., 2008). Thus, the decrease in chlorophyll across experiments and treatments at 28 DAT could be attributed to an insufficient supply of nutrients during this rapid stage of growth, or is merely a function of developmental age (de Sales et al., 2021). Also, the trend of chlorophyll accumulation was different for control plants, which exhibited a maximum chlorophyll content at 7 DAT, with subsequent declines at 14, 21, and 28 DAT in both Expts. 1 and 2. This can also be correlated to a decrease in chlorophyll content
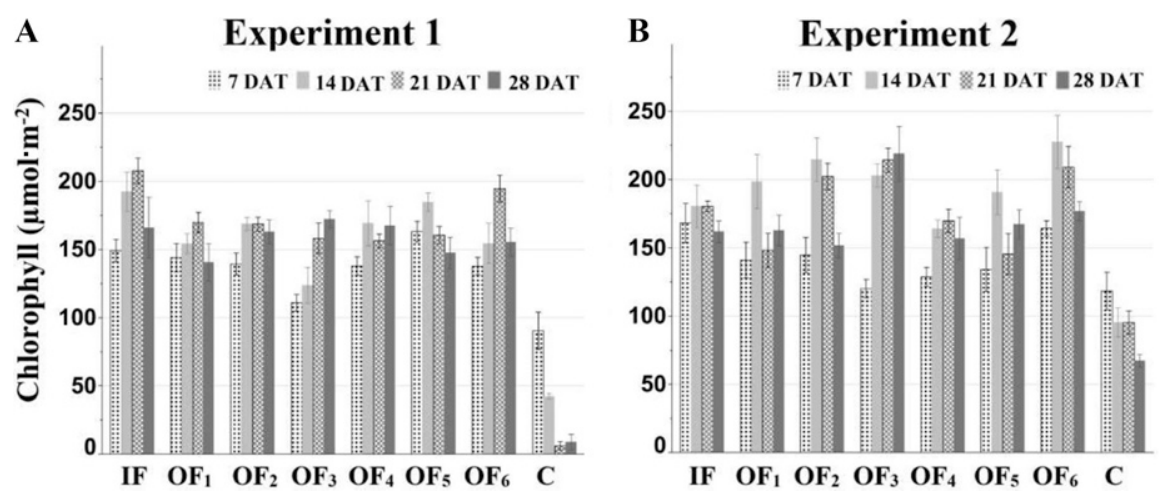

Fig. 3. Butterhead lettuce (Lactuca sativus cv. Rex) chlorophyll concentration from Expt. 1 (A) and Expt. 2 (B). Bars represent the mean \pm SE of four replications. $\mathrm{C}=$ no fertilizer treatment; DAT $=$ days after treatment; IF = inorganic fertilizer, $\mathrm{OF}=$ organic fertilizer. resulting from nutrient stress exhibited after 7 $\mathrm{d}$ because the control treatment was not supplied with any nutrients. Also, the chlorophyll content for the control treatment plants at 7 DAT was less than the chlorophyll content of plants undergoing fertilized treatments.

The chlorophyll content for leaves from fertilized treatments was greater on all sampling dates compared with the control treatment (Fig. 3). Our results are in agreement with research by Zandvakili et al. (2019), who reported greater SPAD readings from lettuce leaves from fertilized treatments compared with an unfertilized treatment. Madeira and Varennes (2005) concluded increased N fertilization in sweet pepper (Capsicum annuum L.) increased SPAD readings, total chlorophyll content, and leaf $\mathrm{N}$ concentration of young leaves. Dunn et al. (2018a) also reported that SPAD readings of poinsettia (Euphorbia pulcherrima Willd. ex Klotzsch) leaves had a correlation with $\mathrm{N}$ concentration. Chlorophyll accumulation is dependent on the availability of $\mathrm{N}$ within the media and the $\mathrm{N}$ uptake rate, and is therefore considered a good proxy for $\mathrm{N}$ status (Dunn et al., 2018a, 2018b; Oliveira et al., 2017). The differential performance in chlorophyll accumulation by several $\mathrm{OF}$ treatments indicates that $\mathrm{N}$ availability or uptake rate was affected by the $\mathrm{N}$

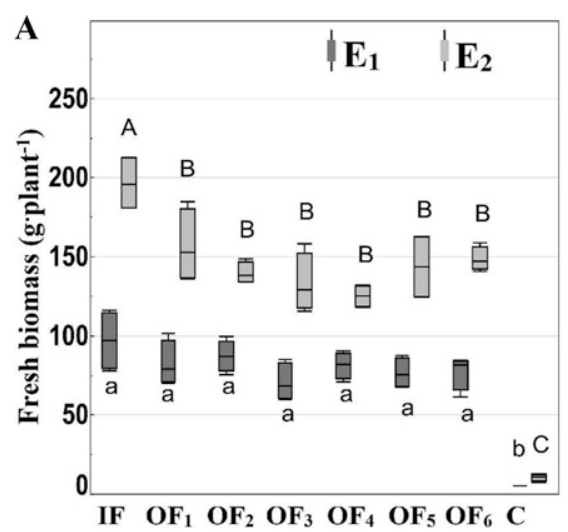

source in each OF. Lettuce growth maximization requires that $\mathrm{N}$ levels be maintained above a critical value (Bottoms et al., 2012). Lettuce is a specialty crop that has stringent standards for quality that includes greenness, which is determined primarily by the chlorophyll content (Agüero et al., 2007; Kowalczyk et al., 2018). The timely delivery of $\mathrm{N}$ to a lettuce crop by OF requires a source of $\mathrm{N}$ where its bioavailability and uptake are not hindered. Therefore, OFs with a greater available $\mathrm{N}$ content could be beneficial for organic lettuce production.

Fresh and dry biomass. In each experiment, the fresh biomass of lettuce plants was greater in all OF treatments and IF treatment compared with control plants (Fig. 4A). The IF treatment recorded the greatest fresh weight during both experiments, whereas fresh biomass was different in all OF treatments only in Expt. 2. Fresh biomass for IFtreated plants was $12 \%$ and $38 \%$ greater than $\mathrm{OF}_{2}$ (the greatest fresh biomass producer among OFs) and $\mathrm{OF}_{3}$ (the lowest fresh biomass producer among OFs), respectively, in Expt. 1, and the same values were $25 \%$ and $57 \%$ greater than $\mathrm{OF}_{1}$ (the greatest fresh biomass producer among $\mathrm{OFs}$ ) and $\mathrm{OF}_{4}$ (the lowest fresh biomass producer among OFs), respectively, in Expt. 2. The results for dry

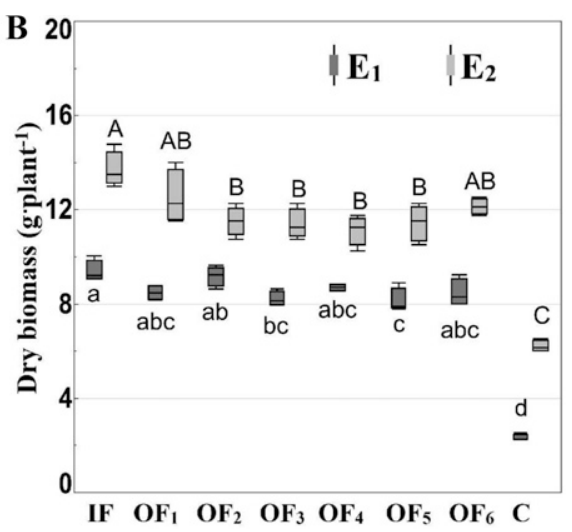

Fig. 4. Butterhead lettuce (Lactuca sativus cv. Rex) fresh biomass (A) and dry biomass (B) measured at $30 \mathrm{~d}$ after transplanting in Expt. $1\left(\mathrm{E}_{1}\right)$ and Expt. $2\left(\mathrm{E}_{2}\right)$ in Lubbock, TX. Box plots represent the mean \pm SE of four replications. Box plots following the same letter in each experiment are not significantly different; lowercase letters are for $\mathrm{E}_{1}$ and uppercase letters are for $\mathrm{E}_{2} . \mathrm{C}=$ no fertilizer treatment; IF = inorganic fertilizer, $\mathrm{OF}=$ organic fertilizer. 
biomass exhibited similar trends as fresh biomass production, and $\mathrm{OF}$ treatments and the IF treatment produced greater dry biomass compared with the control (Fig. 4B). The dry biomass produced from the IF treatment was greater in each experiment, but only different from $\mathrm{OF}_{3}$ and $\mathrm{OF}_{5}$ in Expt. 1. In Expt. 2 , the IF treatment was greater than $\mathrm{OF}_{2}, \mathrm{OF}_{3}, \mathrm{OF}_{4}$, and $\mathrm{OF}_{5}$. The dry biomass for IF-treated plants was $11 \%$ and $14 \%$ greater than $\mathrm{OF}_{2}$ (the greatest dry biomass producer among $\mathrm{OFs}$ ) and $\mathrm{OF}_{3}$ (the lowest dry biomass producer among OFs), respectively, in Expt. 1, and the same values were $10 \%$ and $23 \%$ greater than $\mathrm{OF}_{1}$ (the greatest dry biomass producer among OFs) and $\mathrm{OF}_{4}$ (the lowest dry biomass producer among OFs), respectively, in Expt. 2.

In our study, fresh biomass results for both IF and OF treatments were comparable to previous studies (Singh et al., 2019). Zandvakili et al. (2019) reported the fresh weight of lettuce increased with IF treatment, which was $67 \%$ greater than the OF treatment, and $90 \%$ greater than the unfertilized treatment. Compared with the unfertilized treatment, lettuce fresh weight improved by $72 \%$ with organic fertilization. The authors explained the increased fresh weight of lettuce was the result of readily available nutrients in the IF treatment compared with organic and unfertilized treatments (Zandvakili et al., 2019). An additional greenhouse study concluded fresh biomass of sweet basil was the greatest in a conventional fertilizer treatment $(250$ $\mathrm{kg} \cdot \mathrm{ha}^{-1} \mathrm{~N}$ ) followed by an OF treatment applied at $150 \mathrm{~kg} \cdot \mathrm{ha}^{-1} \mathrm{~N}$ compared with 150 $\mathrm{kg} \cdot \mathrm{ha}^{-1} \mathrm{~N}$ of conventional and $250 \mathrm{~kg} \cdot \mathrm{ha}^{-1} \mathrm{~N}$ OF treatments (Bufalo et al., 2015). The conventional inorganic treatment $\left(250 \mathrm{~kg} \cdot \mathrm{ha}^{-1}\right.$ $\mathrm{N})$, increased the fresh weight yield of sweet basil by $62 \%$ compared with the $150 \mathrm{~kg} \cdot \mathrm{ha}^{-1}$ $\mathrm{N}$ OF treatment. In our study, similar results were found; the IF treatment resulted in greater fresh biomass compared with OFs and the control in each experiment. However, our results are in contrast with those of Drăghici et al. (2016), who reported lettuce plant fresh biomass was greater with one of the liquid organic fertilizer treatments (total $\mathrm{N}, 82.2 \mathrm{~g} \cdot \mathrm{L}^{-1}$ ) compared with a chemical fertilizer treatment (total $\mathrm{N}, 23 \mathrm{~g} \cdot \mathrm{L}^{-1}$ ) using the nutrient film technique. In their study, the researchers found that the greater nutrient rate of the organic fertilizer increased the fresh biomass of lettuce.

Similar to fresh biomass, results for dry biomass production under both IF and OF treatments in our study were in agreement with previous reports. For example, Bufalo et al. (2015) reported the dry biomass of sweet basil was $88 \%$ greater with the $250 \mathrm{~kg} \cdot \mathrm{ha}^{-1} \mathrm{~N}$ conventional fertilizer treatment compared with the $150 \mathrm{~kg} \cdot \mathrm{ha}^{-1} \mathrm{~N}$ organic fertilizer treatment. Biomass accumulation in lettuce production is a direct result of fertility management, which includes fertilizer type, rate, and timing of application (Ahmad et al., 2016). Indeed, optimal fertility requires precise synchronization of nutrient bioavailability and demand, especially during rapid periods of growth (Gaskell and Smith, 2007; Treadwell et al., 2007). Although OF treatments in our study demonstrated reductions in biomass and yield compared with IF, the yield differences among OF and IF treatments could be reduced by optimizing fertility management variables (rate and timing), and by selectin of suitable media substrates (Paillat et al., 2020).

Index-based ranking of organic fertilizers. The growth and yield results presented indicate variability in the effectiveness of each $\mathrm{OF}$ to provide sufficient nutrition for supporting positive growth of lettuce plants. Although growth in Expt. 1 was less than Expt. 2, relative differences among OFs were similar such that a determination of rank could be made. Results indicate RI for six OFs (Table 3 ) correlated well with the performance of each $\mathrm{OF}$, as assessed by percentage yield reductions (Supplemental Table 1). Our results indicate fish-based $\left(\mathrm{OF}_{1}\right)$ and fish- and plant-based $\left(\mathrm{OF}_{2}\right.$ and $\left.\mathrm{OF}_{6}\right)$ liquid $\mathrm{OFs}$ could be used in organic greenhouse lettuce production with proper optimization of rate and timing. The possible reason for an outstanding performance of $\mathrm{OF}_{1}$ could be the greater $\mathrm{N}$ content found in $\mathrm{OF}_{1}$ compared with other fish-based OFs used in our study. The better performance of $\mathrm{OF}_{2}$ and $\mathrm{OF}_{6}$ may be attributed to the greater phosphorus $(\mathrm{P})$ and potassium $(\mathrm{K})$ content in their composition. $\mathrm{OF}_{2}$ had a lower number of leaves compared with $\mathrm{OF}_{6}$, but $\mathrm{OF}_{2}$ was ranked greater than $\mathrm{OF}_{6}$ because of its greater fresh and dry biomass. This is likely a result of greater $\mathrm{P}$ concentrations in $\mathrm{OF}_{2}$, and $\mathrm{OF}_{2}$ plants had thicker stems resulting in greater fresh and dry biomass compared with $\mathrm{OF}_{6}$ plants. Previous research conducted by Soundy et al. (2001) also reported the stem diameter of lettuce increased quadratically with greater P fertilization. Therefore, we can deduce OFs should contain adequate amounts of $\mathrm{N}, \mathrm{P}$, and $\mathrm{K}$ for supporting growth and development of lettuce in organic soilless production systems.

\section{Conclusion}

Use of OFs for soilless production of lettuce decreased all yield parameters (fresh biomass, dry biomass, number of leaves, leaf area) compared with plants grown using the under the IF treatment. Stem thickness was the only growth parameter that was greater with one of the tested OFs $\left(\mathrm{OF}_{4}\right)$ compared with the IF treatment. However, lettuce yield grown with OFs was greater than the control treatment. Chlorophyll content was greater in fertilized treatments (IF and OFs) compared with the unfertilized control plants. Based on the index-based ranking, fish-based $\left(\mathrm{OF}_{1}\right)$ and fish-cum-plant-based $\left(\mathrm{OF}_{2}\right.$ and $\mathrm{OF}_{6}$ fertilizers) performed better in comparison with different liquid OFs used in our study. Although yield with OFs was less compared with that under IF, there is a potential to reduce this yield gap by optimized fertility management of these fertilizers. Therefore, future research is needed to investigate the optimized rate, timing, and different placements of these OFs, and the impact OF fertilizers have on soilless production of lettuce.

\section{Literature Cited}

Agüero, M.V., M.V. Barg, A. Yommi, A.Y.A. Camelo, and S.I. Roura. 2007. Postharvest changes in water status and chlorophyll content of lettuce (Lactuca Sativa L.) and their relationship with overall visual quality. J. Food Sci. 73(1):S47S55, https://doi.org/10.1111/j.1750-3841.2007. 00604.x.

Ahmad, A.A., T.J. Radovich, H.V. Nguyen, J. Uyeda, A. Arakaki, J. Cadby, R. Paull, J. Sugano, and G. Teves. 2016. Use of organic fertilizers to enhance soil fertility, plant growth, and yield in a tropical environment, p. 85-108. In: M.L. Larramendy and S. Soloneski (eds). Organic fertilizers: From basic concepts to applied outcomes. IntechOpen Limited, London, UK, https://doi.org/10.5772/62529.

Aldworth, S.J. and J.V. Staden. 1987. The effect of seaweed concentrate on seedling transplants. S. Afr. J. Bot. 53(3):187-189, https://doi.org/ 10.1016/S0254-6299(16)31428-4.

Ali, O., A. Ramsubhag, and J. Jayaraman. 2021. Biostimulant properties of seaweed extracts in plants: Implications towards sustainable crop production. Plants 10:531.

Arunyanark, A., S. Jogloy, C. Akkasaeng, N. Vorasoot, T. Kesmala, R.C. Nageswara Rao, G.C. Wright, and A. Patanothai. 2008. Chlorophyll stability is an indicator of drought tolerance in peanut. J. Agron. Crop Sci. 194(2):113-125, https:// doi.org/10.1111/j.1439-037X.2008.00299.x.

Bi, G., W.B. Evans, J.M. Spiers, and A.L. Witcher. 2010. Effects of organic and inorganic fertilizers on marigold growth and flowering. HortScience 45:1373-1377, https://doi.org/10.21273/ hortsci.45.9.1373.

Bottoms, T.G., R.F. Smith, M.D. Cahn, and T.K Hartz. 2012. Nitrogen requirements and N status determination of lettuce. HortScience 47:1768 1774, https://doi.org/10.21273/HORTSCI.47.12. 1768.

Bufalo, J., C.L. Cantrell, T. Astatkie, V.D. Zheljazkov, A. Gawde, and C.S.F. Boaro. 2015. Organic versus conventional fertilization effects on sweet basil (Ocimum basilicum L.) growth in a greenhouse system. Ind. Crops Prod. 74:249-254, https://doi.org/10.1016/j.indcrop.2015.04.032.

Bunning, M. and P. Kendall. 2012. Salad greens: Health benefits and safe handling. Colo. State Univ., Fort Collins, PhD Diss. 23 Dec. 2021 $<$ https://extension.colostate.edu/topic-areas/ nutrition-food-safety-health/health-benefitsand-safe-handling-of-salad-greens-9-373/>.

Burnett, S.E., N.S. Mattson, and K.A. Williams. 2016. Substrates and fertilizers for organic container production of herbs, vegetables, and herbaceous ornamental plants grown in greenhouses in the United States. Scientia Hort. 208:111-119, https://doi.org/10.1016/j.scienta.2016.01.001.

Craigie, J.S. 2011. Seaweed extract stimuli in plant science and agriculture. J. Appl. Phycol. 23:371393, https://doi.org/10.1007/s10811-010-9560-4.

de Sales, R.A., E.C. de Oliveira, E. Buzatto, R.F. de Almeida, M.J.A. de Lima, S. da Silva Berilli, R.L. Aguiar, M. Lovo, R.P. Posse, J.C. Dos Santos, and W.Z. Quartezani. 2021. Photoselective shading screens as a cover for production of purple lettuce. Sci. Rep. 11(1):1-9, https://doi.org/10.1038/s41598-021-94437-5.

Drăghici, E.M., E. Dobrin, I.O. Jerca, I.M. Barbulescu, S. Jurcoane, and V. Lagunovschi-Luchian. 2016. Organic fertilizer effect on Lettuce (Lactuca sativa L.) cultivated in nutrient film technology. Romanian Biotechnological Letters 21:11905-11913. 
Dunn, B.L., H. Singh, and C. Goad. 2018a. Relationship between chlorophyll meter readings and nitrogen in poinsettia leaves. J. Plant Nutr. 41(12):1566-1575, https://doi. org/10.1080/01904167.2018.1459697.

Dunn, B.L., H. Singh, M. Payton, and S. Kincheloe. 2018b. Effects of nitrogen, phosphorus, and potassium on SPAD-502 and atLEAF sensor readings of Salvia. J. Plant Nutr. 41(13):1674 1683, https://doi.org/10.1080/01904167.2018. 1458874.

Ekinci, M., M. Atamanalp, M. Turan, G. Alak, R. Kul, N. Kitir, and E. Yildirim. 2019. Integrated use of nitrogen fertilizer and fish manure: Effects on the growth and chemical composition of spinach. Commun. Soil Sci. Plant Anal. 50(13): 1580-1590, https://doi.org/10.1080/00103624. 2019.1631324.

Ellis, B. and H. Foth. 1996. Soil fertility. CRC Press, Boca Raton, FL.

Gaskell, M. and R. Smith. 2007. Nitrogen sources for organic vegetable crops. HortTechnology 17:431-441, https://doi.org/10.21273/horttech. 17.4.431.

Gaskell, M., R. Smith, J. Mitchell, S.T. Koike, C. Fouche, T. Hartz, W. Horwath, and L. Jackson. 2007. Soil fertility management for organic crops. Univ. Calif. Agr. Nat. Resour. (Bangk.), https://doi.org/10.3733/ucanr.7249.

Greer, L. and S. Diver. 2000. Organic greenhouse vegetable production: Appropriate technology transfer for rural areas. Fayetteville, AR. 23 Dec. 2021. <https://attra.ncat.org/product/ organic-greenhouse-vegetable-production $/>$.

Hartz, T.K. and P.R. Johnstone. 2006. Nitrogen availability from high-nitrogen-containing organic fertilizers. HortTechnology 16:39-42, https://doi. org/10.21273/HORTTECH.16.1.0039.

Hounsome, N., B. Hounsome, D. Tomos, and G. Edwards-Jones. 2008. Plant metabolites and nutritional quality of vegetables. J. Food Sci. 73(4):R48-R65, https://doi.org/10.1111/j.17503841.2008.00716.x.

Irshad, L.U.B.N.A., S.H.A.H.N.A.Z. Dawar, and M.J. Zaki. 2006. Effect of different dosages of nursery fertilizers in the control of root rot of okra and mung bean. Pak. J. Bot. 38(1):217.

Kim, M.J., Y. Moon, J.C. Tou, B. Mou, and N.L. Waterland. 2016. Nutritional value, bioactive compounds and health benefits of lettuce ( $\mathrm{Lac}$ tuca sativa L.). J. Food Comp. Anal. 49:19-34, https://doi.org/10.1016/j.jfca.2016.03.004.

Kowalczyk, K., L. Sieczko, V. Goltsev, H.M. Kalaji, J. Gajc-Wolska, M. Gajewski, Ł. Gontar, P. Orliński, M. Niedzińska, and M.D. Cetner. 2018. Relationship between chlorophyll fluorescence parameters and quality of the fresh and stored lettuce (Lactuca sativa L.). Scientia Hort. 235:
70-77, https://doi.org/10.1016/j.scienta.2018.02. 054.

Madeira, A.C. and A.D. Varennes. 2005. Use of chlorophyll meter to assess the effect of nitrogen on sweet pepper development and growth. J. Plant Nutr. 28(7):1133-1144, https://doi.org/ 10.1081/PLN-200063133.

Marcelis, L.F.M., E. Heuvelink, and J. Goudriaan. 1998. Modelling biomass production and yield of horticultural crops: A review. Scientia Hort. 74(1-2):83-111, https://doi.org/10.1016/S03044238(98)00083-1.

Mattner, S.W., D. Wite, D.A. Riches, I.J. Porter, and T. Arioli. 2013. The effect of kelp extract on seedling establishment of broccoli on contrasting soil types in southern Victoria, Australia. Biol. Agr. Hort. 29(4):258-270, https://doi. org/10.1080/01448765.2013.830276.

Moncada, A., A. Miceli, and F. Vetrano. 2021. Use of plant growth-promoting rhizobacteria (PGPR) and organic fertilization for soilless cultivation of basil. Scientia Hort. 275:109733, https://doi.org/10.1016/j.scienta.2020.109733.

Oliveira, L.F.R.D., M.L.R.D. Oliveira, F.S. Gomes, and R.C. Santana. 2017. Estimating foliar nitrogen in Eucalyptus using vegetation indexes. Sci. Agr. 74:142-147, https://doi.org/10.1590/ 1678-992X-2015-0477.

Paillat, L., P. Cannavo, F. Barraud, L. HuchéThélier, and R. Guénon. 2020. Growing medium type affects organic fertilizer mineralization and CNPS microbial enzyme activities. Agronomy 10(12):1955, https://doi.org/10.3390/agronomy 10121955.

Parry, C., J.M. Blonquist, Jr., and B. Bugbee. 2014. In situ measurement of leaf chlorophyll concentration: Analysis of the optical/absolute relationship. Plant Cell Environ. 37(11):2508-2520, https://doi.org/10.1111/pce.12324.

Rahman, M.J., M.R. Chawdhery, B. Pahida, M. Quamruzzaman, M.Z. Zakia, and R. Abu. 2019. Growth and yield of hydroponic lettuce as influenced by different growing substrates. Azarian J. Agr. 6(1):1-6, https://doi.org/10.29252/azarinj.001.

Reganold, J.P. and J.M. Wachter. 2016. Organic agriculture in the twenty-first century. Nat. Plants 2(2):15221, https://doi.org/10.1038/ nplants.2015.221.

Ryder, E.J. 1999. Genetics in lettuce breeding: Past, present and future. In: Eucarpia leafy vegetables '99, Olomouc (Czech Republic), 8-11 June 1999. Palacky University.

Shahbandeh, M. 2021. U.S. per capita consumption of fresh lettuce (romaine and leaf) 2000 2020. 20 Oct. 2021. <https://www.statista.com/ statistics/257322/per-capita-consumption-offresh-lettuce-romaine-and-leaf-in-the-us/ $>$.

Shimizu, H., M. Kushida, and W. Fujinuma. 2008. A growth model for leaf lettuce under greenhouse environments. Environ. Control Biol. 46(4):211219, https://doi.org/10.2525/ecb.46.211.

Singh, H., B. Dunn, M. Payton, and L. Brandenberger. 2019. Fertilizer and cultivar selection of lettuce, basil, and swiss chard for hydroponic production. HortTechnology 29:50-56, https:// doi.org/10.21273/HORTTECH04178-18.

Soundy, P., D.J. Cantliffe, G.J. Hochmuth, and P.J. Stoffella. 2001. Nutrient requirements for lettuce transplants using a floatation irrigation system: I. Phosphorus. HortScience 36:1066-1070, https://doi.org/10.21273/HORTSCI.36.6.1066.

Stewart, H. and J. Hyman 2019. Americans still can meet fruit and vegetable dietary guidelines for $\$ 2.10-\$ 2.60$ per day. Amber waves: The economics of food, farming, natural resources, and rural America 2019.

Tei, F., A. Scaife, and D.P. Aikman. 1996. Growth of lettuce, onion, and red beet: 1 . Growth analysis, light interception, and radiation use efficiency. Ann. Bot. 78(5):633-643, https://doi. org/10.1006/anbo.1996.0171.

Tittarelli, F. 2020. Organic greenhouse production: Towards an agroecological approach in the framework of the new European regulation: A review. Agronomy 10(1):72, https://doi.org/ 10.3390/agronomy10010072.

Treadwell, D.D., G.J. Hochmuth, R.C. Hochmuth, E.H. Simonne, L.L. Davis, W.L. Laughlin, Y. Li, T. Olczyk, R.K. Sprenkel, and L.S. Osborne. 2007. Nutrient management in organic greenhouse herb production: Where are we now? HortTechnology 17:461-466, https://doi. org/10.21273/HORTTECH.17.4.461.

Walters, K.J., B.K. Behe, C.J. Currey, and R.G. Lopez. 2020. Historical, current, and future perspectives for controlled environment hydroponic food crop production in the United States. HortScience 55:758-767, https://doi.org/ 10.21273/HORTSCI14901-20.

Willer, H. and A. Sahota. 2020. The world of organic agriculture, statistics and emerging trends 2020 at BIOFACH 2020.

Willer, H. and J. Lernoud (eds.). 2019. The world of organic agriculture: Statistics and emerging trends 2019. 20th ed. Research Institute of Organic Agriculture, Frick, and IFOAM Organics International, Bonn, Germany.

Willer, H., M. Yussefi-Menzler, and N. Sorensen (eds.). 2008. The world of organic agriculture: Statistics and emerging trends 2008. 1st ed. Routledge, London, UK, https://doi.org/10.4324/ 9781849775991.

Zandvakili, O.R., A.V. Barker, M. Hashemi, F. Etemadi, and W.R. Autio. 2019. Comparisons of commercial organic and chemical fertilizer solutions on growth and composition of lettuce. J. Plant Nutr. 42(9):990-1000, https://doi.org/ 10.1080/01904167.2019.1589505. 
Supplemental Table 1. Butterhead lettuce (Lactuca sativus cv. Rex) growth parameter percentage change represented by data pooled from Expts. 1 and 2 using organic fertilizers and no fertilizer compared to inorganic fertilizer treatment at Lubbock, TX.

\begin{tabular}{|c|c|c|c|c|}
\hline Treatment & Fresh biomass & Leaf area & No. of leaves & Dry biomass \\
\hline$\overline{\mathrm{OF}_{1}}$ & -17.5 & -19.2 & -4.5 & -9.2 \\
\hline $\mathrm{OF}_{2}$ & -18.7 & -15.5 & -8.6 & -9.0 \\
\hline $\mathrm{OF}_{3}$ & -29.7 & -30.2 & -11.8 & -14.6 \\
\hline $\mathrm{OF}_{4}$ & -25.4 & -34.9 & -8.1 & -12.9 \\
\hline $\mathrm{OF}_{5}$ & -23.7 & -24.8 & -9.8 & -14.9 \\
\hline $\mathrm{OF}_{6}$ & -21.7 & -23.3 & -7.3 & -10.7 \\
\hline Control & -94.8 & -95.4 & -62.0 & -65.0 \\
\hline
\end{tabular}

$\overline{\mathrm{OF}}=$ organic fertilizer. 